\title{
Human fluorosis related to volcanic activity: a review
}

\author{
W. D’Alessandro \\ Istituto Nazionale di Geofisica e Vulcanologia - Sezione di Palermo, \\ Palermo, Italy
}

\begin{abstract}
Fluorosis is a widespread disease related to ingestion of high levels of fluorine through water and food. Although sometimes of anthropogenic origin, high levels of fluorine are generally related to natural sources. One of the main sources is represented by volcanic activity, which releases magmatic fluorine generally as hydrogen fluorine through volcanic degassing. For example, Mt. Etna in Italy is considered the greatest point source at the global scale, releasing on average $70 \mathrm{Gg}$ of $\mathrm{HF}$ each year. But the impact of fluorine on human health is highly dependent on its chemical state, which means that high rates of release do not necessarily point to high impacts. The major pathway of magmatic fluorine to humans is in the form of fluoride ion $\left(\mathrm{F}^{-}\right)$, through consumption of contaminated vegetables and drinking water. Contamination can happen either through direct uptake of gaseous HF or through rainwaters and volcanic ashes. Furthermore hydrogen fluoride, being one of the most soluble gases in magmas, exsolves only partially $(<20 \%)$ during volcanic activity. Volcanic rocks thus contain high levels of fluorine, which are transferred to groundwaters through water-rock interaction processes in the aquifers. Large magmatic provinces, like for example the East African Rift Valley, are therefore endemic for fluorosis. Finally a literature review of volcanic related fluorosis is given.
\end{abstract}

Keywords: fluorosis, magmatic fluorine, volcanic activity, groundwater.

\section{Introduction}

The influence of the geological environment on human health has long been known with the first links being recognized probably by Chinese physicians in 
the $4^{\text {th }}$ century [1]. Such influence is related not only to excessive intake of particular elements but also to their deficiency. For fluorine, like for a few other elements (e.g. I, Se), human health status depends upon a delicate balance between excess and deficiency. Low intake of this element is related to dental caries while exposure to high chronic levels can lead to dental or skeletal fluorosis [2].

Many natural geological processes, sometimes exacerbated from anthropogenic influences (mining activities, fuel combustion, etc.), can be responsible of the impact of harmful compounds. One of the most important is volcanic activity. Apart from the obvious impact of eruptive, especially explosive, activity, in recent times the scientific community has become aware of the effects on the environment and particularly on human health deriving from geochemical processes acting in quiescent periods and even in volcanic systems considered extinct. The importance of this new scientific branch brought specialists of different disciplines to join in the International Volcanic Health Hazard Network (IVHHN) with the common aim of trying to better define the health effects of volcanic emissions [3].

\subsection{Magmatic fluorine}

Fluorine is the $13^{\text {th }}$ most abundant element in the earth's crust [4]. Several natural and anthropogenic sources contribute to the geochemical cycling of fluorine. The most important industrial processes that release fluorine compounds are: aluminium smelting, coal burning, phosphate fertiliser and cement production, and brick and ceramic firing [5].

Volcanoes represent the main natural persistent source of fluorine [6,7]. Fluorine is emitted by volcanoes mostly in the form of $\mathrm{HF}_{(\mathrm{g})}$ [6], but emissions also contain much lower amounts of gaseous $\mathrm{NH}_{4} \mathrm{~F}, \mathrm{SiF}_{4},\left(\mathrm{NH}_{4}\right)_{2} \mathrm{SiF}_{6}, \mathrm{NaSiF}_{6}$, $\mathrm{K}_{2} \mathrm{SiF}_{6}, \mathrm{KBF}_{4}$ and organo-fluorides [4, 8, 9]. Volcanic emissions of fluorine take the form of either sluggish permanent release from quiescent volcanoes (passive degassing) or rarer but more impacting discharges during short-lived volcanic eruptions. Estimates of the global volcanogenic fluorine flux range 50 to 8600 $\mathrm{Gg} / \mathrm{a}[6,7,10]$, with the former figure being probably an underestimate. Total anthropogenic emissions are in the same order of magnitude with the highest emissions are due to chlorofluorocarbon production ( $300 \mathrm{Gg} / \mathrm{a})$ and coal burning $(200 \mathrm{Gg} / \mathrm{a})$ [5].

It has been estimated that passive degassing, like that existing at Mt. Etna (Italy) and Masaya (Nicaragua) volcanoes, accounts for about $90 \%$ of the volcanic fluorine release. In particular Mt. Etna is the largest known point source of atmospheric fluorine, contributing for about $70 \mathrm{Gg} / \mathrm{a}$ [11], even stronger than today's total estimated anthropogenic release over Western Europe [12]. The influence of these emissions on the surrounding environment and in particular on vegetation has been investigated by several authors [12-14].

Although responsible on average for the emission of lower amounts, the impact of fluorine emitted during explosive volcanic eruptions has been better studied [15-17]. Fluoride was certainly the agent responsible for the death of sheep after the volcanic eruption described in the Icelandic sagas. Ashes emitted 
during explosive activity scavenge very effectively the erupted volcanic gases including HF thus enhancing their deposition around the erupting volcano up to distances of hundreds of $\mathrm{km}$ [15]. Acute and chronic fluorosis on grazing animals has been described for many explosive eruptions all around the world (Mt. Hekla - Iceland [18], Lonquimay - Chile [19], Nyamuragira - Democratic Republic of Congo [20], Mt. Ruapehu - New Zealand [17]). Consequences on livestock are due either to direct ingestion of F-rich ashes deposited on the grass or to grazing of grass or drinking water that are F-contaminated. The problem is widespread in Iceland were the magmas are particularly F-rich. Since it's settling in $9^{\text {th }}$ century many eruptions on Iceland were responsible of F-poisoning of livestock. The first account of this problem was made after the 1693 eruption of Mt. Hekla by the farmer Eiriksson and the clergyman Petursson, which described the deformed teeth in sheep, cattle and horse calling them "ash-teeth" [21]. Death due to F-poisoning of livestock caused serious famines among Icelanders who were totally dependent on them. The worst episode followed the Laki eruption in 1783 causing the death of half of the population of Iceland [21].

Chronic fluorosis on grazing animals was also related to passive degassing (Ambrym, Vanuatu [22]) and to geothermal activity in recent volcanic areas (Yellostone, U.S.A. [23]).

\subsection{Human fluorosis}

Fluorine is an essential element for human growth being incorporated in the mineral part of bones and in teeth in the form of fluoroapatite. Dental fluorosis is characterised by discoloured, blackened, mottled or chalky-white teeth. These symptoms are connected with an overexposure to fluoride during childhood when teeth were developing [5]. Fluorine intake above safe limit for very long time or in very high amounts can lead to skeletal fluorosis, with severe and permanent bone and joint deformations [5].

The main route of intake for humans is through drinking water. Only rarely high fluorine intake may derive from F-rich vegetables due either to natural accumulation (tea) or to anthropogenic contamination [24]. Absorption through the skin is very low but HF causes severe burns. Also the contribution of inhalation to the body burden of fluorine is very low. Workers exposed to high HF concentrations have higher probabilities to develop asthma or chronic lung diseases rather than fluorosis [5].

Fluorine, which is accumulated by vegetation as fluoride ion, is readily adsorbed by herbivorous animals. Animals accumulate this element as fluoroapatite that is relatively inert so that fluorine will not be biomagnificated in flesh-eating animals.

Whether dental or skeletal fluorosis are irreversible and no treatment exists, the only remedy being prevention by keeping fluoride intake within safe limits. The World Health Organization fixed a maximum admissible limit of $1.5 \mathrm{mg} / \mathrm{l}$ for drinking water [5], although for hotter climates this limit should be lowered to $1.0 \mathrm{mg} / \mathrm{l}$ due to higher water consumption. 
Third world populations are more prone to develop fluorosis because of bad nutritional status. Clinical data indicate that to low protein, calcium and vitamin $\mathrm{C}$ and $\mathrm{D}$ intake raises the dental fluorosis risk [25, 26].

A conservative estimate indicates that fluorosis affects tens of millions of people and is endemic in at least 25 countries across the globe [25]. Among these, Japan, New Zealand, Mexico and the countries along the east African Rift Valley (Eritrea, Ethiopia, Uganda, Kenia and Tanzania) display widespread volcanic activity.

\section{Review of human fluorosis related to volcanic activity}

The problem of fluorosis related to volcanic activity was first recognised in Japan were this pathology was called "Aso volcano disease" [27] due to the fact that fluorosis was widespread in the population living at the foot of this volcano.

Water intake being the main route of fluorine into the human body, fluorosis in volcanic areas is generally associated to elevated fluoride content in surfaceand ground-waters. Contamination of vegetation, which is the main agent of volcanic-related fluorosis in herbivorous animal, is only of secondary importance for human health.

High fluorine content in waters derive either from water-rock interaction (WRI) processes in volcanic aquifers (groundwaters) or to contamination due to wet or dry deposition of magmatic fluorine (surface waters - reservoirs).

Furthermore, paleopathologic studies on human skeletons found in Herculaneum, referable to victims of 79 AD eruption of Mt. Vesuvius, evidenced that fluorosis in this area had the same incidence as in modern times, pointing to the constancy of the geochemical processes responsible for fluorine enrichment of the drinking water in the area over at least the last 2000 years [28].

\subsection{Water-rock interaction}

Volcanic rocks are often enriched in fluorine. Hydrogen fluorine is, in fact, one of the most soluble gases in magmas and exsolves only partially during eruptive activity. Burton et al. [29] estimated for example that Etnean magmas exsolve only about $20 \%$ of their initial HF content during effusive activity. Furthermore fluorine behaves as incompatible element being highly enriched in differentiated volcanic products [30].

In volcanic aquifers elevated temperatures and/or strong acidic conditions enhance WRI processes. Such conditions often lead to high concentrations of harmful elements [31]. Therefore fluorine concentrations in volcanic aquifers above safe drinking limits are rather the rule than the exception. Values as high as tens of $\mathrm{mg} / \mathrm{l}$ of fluorine are often achieved in groundwaters, which if used for human consumption can easily lead to skeletal fluorosis.

Dental fluorosis due to groundwaters enriched by WRI in recent or active volcanic areas has been assessed in many parts of the world. Many articles illustrate such cases. Some of them refer to limited areas like Gölcük - SW Turkey [32], Mt. Aso volcano, Japan [27], Island of Tenerife - Spain [33], 
Furnas volcano, São Miguel - Azores, Portugal [34], Albano Lake - Italy [35], while other evidence a widespread problem throughout entire countries like Mexico [36], Ethiopia [37], Kenya [38], Tanzania [26]. In these areas, populations as high as 200,000 people could be at risk to develop fluorosis like for example the inhabitants of the Los Altos the Jalisco region in Mexico [39].

Particularly high fluorine concentrations (thousands of $\mathrm{mg} / \mathrm{l}$ ) can only be achieved under extreme conditions, partially or totally ascribable to volcanic activity. Lakes along the East Africa Rift Valley display values as high as 1980 mg/l (Lake Magadi - Kenia [40]). Such high contents originate from geothermal weathering of the F-rich volcanic rocks further concentrated by evaporative processes in arid climate. Calcium concentrations in these lakes, which could limit fluorine concentrations through fluorite precipitation, are very low due to precipitation of carbonate phases in a highly alkaline environment.

Very acidic lakes in active volcanic systems $(\mathrm{pH}$ values $\approx 0)$ can also achieve extreme fluorine concentrations not only due to intense WRI processes but also to direct input of F-rich volcanic gases. Lakes like Poas - Costa Rica [41] and Ijen Crater Lake - Indonesia [42] reach concentrations far above $1000 \mathrm{mg} / \mathrm{l}$.

Seepage or effluent rivers from these extremely F-rich lakes can easily contaminate ground- or surface waters. It has been estimated that the Ijen Crater Lake discharges daily in the surface and groundwaters of the highly populated area of Asembagus about $2800 \mathrm{~kg}$ of fluorine [42], which is responsible of the widespread occurrence of fluorosis in the area. Furthermore the fluorine contained in the salts extracted from the shores of the East African Rift Valley lakes and used for cooking purposes represent an additional fluorine source for the local population [26].

\subsection{Degassing activity}

Persistent open conduit degassing being the main source of fluorine to the atmosphere can be also the source of contamination of water resources close to volcanoes. In two volcanic systems, high magmatic fluorine deposition has been correlated to human fluorosis.

Stromboli Island - Italy releases $2 \mathrm{Gg} / \mathrm{a}$ of fluorine of which about $1 \%$ is deposited on its flanks [43]. Deposition decreases exponentially from the summit craters $\left(70 \mathrm{mg} / \mathrm{m}^{2} / \mathrm{d}\right)$ to the periphery of the island $\left(0.5-1 \mathrm{mg} / \mathrm{m}^{2} / \mathrm{d}\right)$. Up to few decades ago the inhabitants of Stromboli derived their water resources mainly from rainwater collection. A recent study highlighted volume weighted mean values of fluorine in rainwater ranging from 0.4 to $1.9 \mathrm{mg} / \mathrm{l}$ in the inhabited area of the island were rainwater was collected $[43,44]$. Such concentrations are high enough to cause dental fluorosis and actually elderly people suffer from this pathology. Nowadays people all drink bottled water and most of the water for domestic use is brought by ship from the Sicilian mainland so that young people do not show any sign of dental fluorosis.

Recent studies assessed that Ambrym volcano - Vanuatu releases enormous amount of HF (up to $400 \mathrm{Gg} / \mathrm{a}$ ) with severe environmental consequences [22]. Fluorosis is widespread on the island and is due to contamination of drinking 
water resources (mainly rainwater) and vegetables through abundant fluorine deposition [22].

\subsection{Explosive activity}

During explosive activity huge quantities of fluorine are deposited with ashes around the volcano up to distances of hundreds of $\mathrm{km}$. Contamination is in this case generally of short duration because of permanent adsorption of fluorine in soils and dilution through rainwaters, and generally does not bring to chronic expositions of humans. The most exposed to the transient high fluorine levels are herbivorous animals.

The only known eruption that had also consequences on humans was that of Laki - Iceland in 1783. The Icelandic clergyman and historian Jon Steingrimsson, who described in detail all consequences of fluorine intoxication on livestock, tells us also that some of the people living in the area most affected by ashfall developed the same bone and teeth deformations like the animals [21]. In this case fluorosis affected people who had to live on food and to drink water that were contaminated by fluorine. The consequences were probably worsened by the bad nutritional status deriving from the food shortage that followed the eruption. Furthermore this was a long-lasting eruption, exposing people to very high fluorine levels for many months.

\section{Remediation}

There are basically two approaches for treating water supplies to remove fluoride: flocculation and adsorption [45]. In the former method fluoride is removed through reaction with chemicals (generally hydrate aluminium salts) that coagulating into flocs settle at the bottom of the container. The other method is to filter water down through a column packed with a strong adsorbent, such as activated alumina, activated charcoal or ion exchange resins. Both methods can be used for community or household treatment plants but often their exercise costs are to high for third world countries.

Resent research highlighted the strong fluoride sorption properties of volcanic soils, which are readily available in volcanic areas $[45,46]$. The high content of amorphous phases of aluminium (allophane, imogolite), clay minerals and organic bound aluminium enhance fluoride adsorption properties.

Volcanic soils exert their defluoridation properties also naturally. Bellomo et al. [43] evidenced that the soils of Mt. Etna adsorb about 70\% of the magmatic fluorine deposited on its flanks protecting the huge groundwater resources and maintaining the fluoride concentration always below the safe drinking water level.

\section{Concluding remarks}

Fluorosis is generally not considered in the volcanic hazard evaluation of volcanic systems. Nevertheless fluorosis related to volcanic activity affects probably, at the global level, nearly some million of people. In the majority of 
cases this brings only little sufferance or even only aesthetic problems (dental fluorosis) but in the worst cases it can bring to complete inability (skeletal fluorosis).

Problems of magmatic fluorine contamination have to be managed in different ways. Contamination due to WRI processes has to be resolved with methodologies attaining correct water resource management, i.e. searching alternative (low-F) water sources or applying water treatment methods. It has to be highlighted that while in the more evolved nations fluorosis is generally declining because there are enough economic resources to find alternative water sources (i.e. Stromboli and Furñas) or to apply correct water treatments, in the less evolved nations the problem is still increasing. This depends on many reasons. One is the constant population growth in third world nations, particularly in the highly fertile volcanic areas [47], exposing an increasing number of people to the risk of fluorosis (and other volcanic risks). Furthermore in some of these countries, which often suffer for arid climate and consequent water shortage problems, emphasis is usually on water availability rather than quality. But while in some cases, discoloured teeth may be an acceptable side effect of the overriding need to provide microbially clean, easily accessible and cheap drinking water, in some country of the East African Rift Valley maximum admissible concentrations in drinking waters $(3 \mathrm{mg} / \mathrm{l}$ in Ethiopia and $8 \mathrm{mg} / \mathrm{l}$ in Tanzania) expose people to the more serious consequences of skeletal fluorosis.

Fluorine contamination due to eruptive activity often requires emergency management. One of the major tools is quantitative modelling that gives important information for the identification of exposure pathways and for the fluorosis risk management. The problem was discussed in two recent papers. One deals with the contamination of rainwater tanks and open drinking water reservoirs through volcanic ashes [48]. The risk connected to this type of contamination depends on the quantity of leachable fluorine adsorbed by ashes and the ash/water mass ratio in the contaminated reservoir. The other paper applies mathematical models, developed by the U.S. Environmental Agency, to different volcanic activity scenarios [49]. The risk assessment was applied to quantitatively estimate exposure pathways and daily average intake of fluoride in hypothetical fluoride-contaminated volcanic areas.

\section{References}

[1] Appleton, J.D., Fuge, R., McCall, G.J.H. (eds.) Environmental Geochemistry and Health, Geological Society Special Publ. 113, 1996.

[2] Edmunds, W.M., Smedley, P.L., Groundwater geochemistry and health: an overview. Appleton, J.D., Fuge, R., McCall, G.J.H. (eds.) Environmental Geochemistry and Health, Geological Society Special Publ. 113, 1996.

[3] http://www.ivhhn.org/.

[4] Weinstein, L.H., Davison, A., Fluoride in the Environment, CABI Publishing, 2003. 
[5] WHO, Fluorides, Geneva, World Health Organization. Environmental Health Criteria 227, pp. 268, 2002.

[6] Symonds, R.B., Rose, W.I., Reed, M.H., Contribution of Cl- and Fbearing gases to the atmosphere by volcanoes, Nature, 334, 415-418, 1988 .

[7] Halmer, M.M., Schmincke, H.U., Graf, H.F., The annual volcanic gas input into the atmosphere, in particular into the stratosphere: a global data set for the past 100 years, J. Volcanol. Geoth. Res., 115, 511-528, 2002.

[8] Francis, P., Chaffin, C., Maciejewski, A., Oppenheimer, C., Remote determination of $\mathrm{SiF}_{4}$ in volcanic plumes: A new tool for volcano monitoring, Geophys. Res. Lett., 23(3), 249-252, 1996.

[9] Schwandner, F.M., Seward, T.M., Gize, A.P., Hall, P.A., Dietrich, V.J., Diffuse emission of organic trace gases from the flank and the crater of a quiescent active volcano (Volcano, Aeolian Islands, Italy), J. Geophys. Res., 109, D04301, 2004.

[10] Cadle, R.D., A comparison of volcanic with other fluxes of atmospheric trace gas constituents, Rev. Geophys., 18, 746-752, 1980.

[11] Francis, P., Burton, M.R., Oppenheimer, C., Remote measurements of volcanic gas compositions by solar occultation spectroscopy, Nature, 396, 567-570, 1998.

[12] Aiuppa, A., Bellomo, S., Brusca, L., D’Alessandro, W., Di Paola, R., Longo, M., Major ion bulk deposition around an active volcano (Mt. Etna, Italy), Bull. Volcanol., 68, 255-265, 2006.

[13] Garrec, J.P., Plebin, R., Faivre-Pierret, R.X., The Influence of volcanic fluoride emissions on surrounding vegetation, Fluoride, 10, 152156,1984 .

[14] Notcutt, G., Davies, F., Accumulation of volcanogenic fluoride by vegetation: Mt. Etna, Sicily, J. Volcanol. Geotherm. Res., 39, 329-333, 1989.

[15] Oskarsson, N., The interaction between volcanic gases and tephra: fluorine adhering to tephra of the 1970 Hekla eruption, J. Volcanol. Geotherm. Res., 8, 251-266, 1980.

[16] Thorarinsson, S., On the damage caused by volcanic eruptions with special reference to tephra and gases, In: Sheets, P.D., Grayson, D.K. (eds.), Volcanic activity and human ecology, Academic Press, New York, p. 125-159, 1979.

[17] Cronin, S.J., Neall, V.E., Lecointre, J.A., Hedley, M.J., Loganathan, P., Environmental hazards of fluoride in volcanic ash: a case from Ruapehu volcano, New Zealand, J. Volcanol. Geotherm. Res., 121, 271-291, 2002.

[18] Georgsson, G., Petursson, G., Fluorosis of sheep caused by the Hekla eruption in 1970, Fluoride, 5(2), 58-66, 1972.

[19] Araya, O., Wittwer, F., Villa, A., Ducom, C., Bovine fluorosis following volcanic activity in the southern Andes, Vet. Rec., 126, 641-642, 1990.

[20] Casadevall, T.J., Lockwood, J.P., Active volcanoes near Goma, Zaire: hazard to residents and refugees, Bull. Volcanol., 57, 275-277, 1995. 
[21] Fridriksson, S., Fluoride problems following volcanic eruption, In: Shupe, J.L., Peterson, H.B., Leone, N.C., (Eds.) Fluorides, - Effect on vegetation, animals and humans, Pearagon Press, UT, 339-344, 1983.

[22] Crimp, R., Cronin, S., Charley, D., Oppenheimer, C., Bani, P., Dental fluorosis attributed to volcanic degassing on Ambrym, Vanuatu, Cities on Volcanoes 4, Quito, Ecuador, 23-27 January 2006, Abstract book, 2006.

[23] Garrot, R.A., Eberhardt, L.L., Otton, J.K., White, P.J., Chaffee, M.A., A geochemical trophic cascade in Yellowstone's geothermal environments, Ecosystems, 5, 659-666, 2002.

[24] Ando, M., Todano, M., Yamamoto, S., Tamura, K., Asanuma, S., Watanabe, T., Kondo, T., Sakurai, S.J.R., Liang, C., Chen, X., Hong, Z., Cao, S., Health effects of fluoride caused by coal burning, Sci. Total Environ., 271, 107-116, 2001.

[25] Qian, J., Susheela A.K., Mudgal, A., Keast, G., Fluoride in water: an overview, Waterfront, 13, 11-13, 1999.

[26] Nanyaro, J.T., Aswathanarayana, U., Mungure, J.S., Lahermo, P.W., A geochemical model for the abnormal fluoride concentration in waters in parts of northern Tanzania, J. African Earth Sci., 2, 129-140, 1984.

[27] Kawahara, S., Odontological observations of Mt. Aso-volcano disease, Fluoride, 4, 172-175, 1971.

[28] Morettini, L., Ciranni, R., Herculaneum - other mysteries unearthed, C.N.R., Bologna, 2000.

[29] Burton, M., Allard, P., Murè, F., Oppenheimer, C., FTIR remote sensing of fractional magma degassing at Mt. Etna, Sicily, In: Volcanic degassing, Oppenheimer, C., Pyle, D., Barclay, J. (eds) Geol. Soc. London Spec. Publ. 213, 281-293, 2003.

[30] Sigvaldason, G.E., Oskarsson, N., Fluorine in basalts from Iceland, Contr. Mineral. Petrol., 94, 263-271, 1986.

[31] Aiuppa, A., D’Alessandro, W., Federico, C., Palumbo, B., Valenza, M., The aquatic geochemistry of arsenic in volcanic groundwaters from southern Italy, Appl. Geochem., 18, 1283-1296, 2003.

[32] Pekdeger, A., Özgür, N., Schneider, H.J., Hydrogeochemistry of fluoride in shallow aqueous systems of the Gölcük area, SW Turkey, In: Kharaka, Y.K., Maest, A.S. (eds) Proc. $7^{\text {th }}$ Intern. Symp. on Water Rock Interaction, Utah, 821-824, 1992.

[33] Hardisson, A., Rodriguez, M.I., Burgos, A., Diaz Flores, L., Gutierrez, R., Varela, H., Fluoride levels in publicly supplied and bottled drinking water in the island of Tenerife, Spain, Bull. Environ. Contam. Toxicol., 67, 163170, 2001.

[34] Baxter, P.J., Buabron, J.C., Coutinho, R., Health hazards and disaster potential of ground gas emissions at Furnas volcano, São Miguel, Azores, J. Volcanol. Geotherm. Res., 92, 95-106, 1999.

[35] Beccari, M., Dall'Aglio, M., Nuove frontiere nell'approvvigionamento di acque per usi civili ed agricoli alla luce della loro accettabilità, Atti del Convegno dell'Accademia dei LINCEI pp. 99-127, “Accettabilità delle acque per usi civili ed agricoli”. Roma, 5 Giugno 2002. 
[36] Soto-Rojas, A.E., Ureña-Cirett, J.L., Martínez-Mier E.A., A review of the prevalence of dental fluorosis in Mexico, Pan Am. J. Public Health, 15, 9$17,2004$.

[37] Kloos, H., Tekle Haimanot, R., Distribution of fluoride and fluorosis in Ethiopia and prospects for control, Tropical Medicine and International Health, 4, 355-364, 1999.

[38] Nyaora Moturi, W.K., Tole, M.P., Davies, T.C., The contribution of drinking water towards dental fluorosis: a case study of Njoro Division, Nakuru District, Kenya, Environ. Geochem. Health, 24, 123-130, 2002.

[39] Hurtado, R., Gardea-Torresdey, J., Tiemann, K.J., Fluoride occurrence in tap water at "Los Altos de Jalisco" in the central Mexico region, Proc. of the 2000 Conf. on Hazardous Waste Research, 211-219, 2000.

[40] Jones, B.F., Eugster, H.P., Reitig, S.L., Hydrogeochemistry of the Lake Magadi Basin, Kenya, Geochim. Cosmochim. Acta, 41, 53-72, 1977.

[41] Rowe, G.L., Brantley, S.L., Fernandez, J.F., Borgia, A., The chemical and hydrologic structure of Poas Volcano, Costa Rica, J. Volcanol. Geotherm. Res., 64, 233-267, 1995.

[42] Heikens, A., Sumarti, S., van Bergen, M., Widianarko, B., Fokkert, L., van Leeuwen, K., Seinen, W., The impact of the hyperacid Ijen Crater Lake: risks of excess fluoride to human health, Sci. Total Environ., 346, 56-69, 2005.

[43] Bellomo, S., D'Alessandro, W., Longo, M., Volcanogenic fluorine in rainwater around active degassing volcanoes: Mt. Etna and Stromboli island, Italy, Sci. Total Environ, 301, 175-185, 2003

[44] Liotta, M., Brusca, L., Grassa, F., Inguaggiato, S., Longo, M., Madonia, P., Geochemistry of rainfall at Stromboli volcano (Aeolian Islands): isotopic composition and plume-rain interaction, Geochem. Geophys. Geosyst., in press, 2006.

[45] Bjorvatn, K., Reimann, C., Østvold, S.H., Tekle-Haimanot, R., Melaku, Z., Siewers, U., High-fluoride drinking water. A health problem in the Ethiopian Rift Valley. 1. Assessment of lateritic soils as defluoridating agents, Oral Health \& Preventive Dentistry 1, 141-148, 2003.

[46] Zevenberger, C., van Reeuwijk, L.P., Frapporti, G., Louws, R.J., Schuiling, R.D., A simple method for defluoridation of drinking water at village level by adsorption on Ando soil in Kenya, Sci. Total Environ., 188, 225-232, 1996.

[47] Small, C., Naumann, T., The global distribution of human population and recent volcanism, Environ. Hazards, 3, 93-109, 2001.

[48] Stewart, C., Johnston, D.M., Leonard, G.S., Horwell, C.J., Thordarson, T., Cronin, S.J., Modelling contamination of water supplies by volcanic ashfall, J. Volcanol. Geotherm. Res., in press, 2006.

[49] Delmelle, P., A quantitative look at fluoride exposure and intake of residents in volcanic areas using a health risk assessment approach, Cities on Volcanoes 4, Quito, Ecuador, 23-27 January 2006, Abstract book, 2006. 